\title{
MANAGEMENT
}

Received:

4 September, 2019

1st Revision:

4 October, 2019

Accepted:

9 October, 2019
UDC: 338

DOI https://doi.org/10.26661/2522-1566/2019-3/09-01

\section{THE IMPLICATION OF LEAN PROCESS INDUSTRY 4.0 ON SERVICE COMPANY: MOTIVATION ON MARKETER PRODUCTIVITY ENHANCEMENT}

\author{
Dhayawardhana Adhie \\ BINUS Business School \\ Bina Nusantara University \\ Jakarta, Indonesia \\ ORCID: 0000-0001-6463-0376
}

\author{
Jemy Wicaksono \\ BINUS Business School \\ Bina Nusantara University \\ Jakarta, Indonesia \\ ORCID: 0000-0001-8465-9918
}

\author{
Ahmad Syamil \\ BINUS Business School \\ Bina Nusantara University, \\ Jakarta, Indonesia \\ ORCID: 0000-0001-8770-9570
}

*Corresponding author email: wicaksonojemy12@gmail.com

Abstract. Industry 4.0 is known as a continuous industrial revolution which has made rapid development through optimization processes supported by technological innovations since the end of the 1970's. It has made the manufacturing industry become more productive with efficient operational costs through continuous technology information applications supported by the communication systems of futuristic technology. However, obstacles were often found in the early phases of the implementations, such as the low number of acquired accounts and average balances of new acquired customers in the months measured by marketers' productivity in field. One of the factors that influenced the employee productivity level was motivation. Motivation is considered as a power that forces employees to reach specific goals and targets in organizations. This study aimed to determine the factors that influence working motivation in the financial service sector industry based on mobile banking applications. It also sought to find how far motivation influences employees' working performance. A regression analysis approach was applied as method to find the effect of employee's motivation on working performance by adding other variables. Then, the variable was analyzed whether it had a positive and significant correlation with the performance productivity variable. The result showed that there was a significant and positive correlation between motivation and marketers' performance productivity. The other two variables gave a different response. Therefore, it can be concluded that industry differentiation on product, working pattern, and employee's background were affecting the suitability result between employee's motivation and produced performance level.

Keywords: industry 4.0, motivation, rewards, promotion, people development, performance, productivity performance.

JEL Classification: L1, M1, M21.

\section{INTRODUCTION}

In the industry 4.0 era, the service sector of banking should be able to adapt to the rapid technology development, especially in digital technology. The survey of the State of Banking Innovation on 2016 stated that the main point mentioned by respondents from senior bankers was the need for mobile-based financial technology for future banks. B Bank is one of the foreign 
Dhayawardhana Adhie, Jemy Wicaksono and Ahmad Syamil (2019). "The implication of lean process Industry 4.0 on service company: motivation on marketer productivity enhancement", Management and entrepreneurship: trends of development, 3(09), pp. 8-20. DOI: https://doi.org/10.26661/2522-1566/2019-3/09-01

exchange banks with a capital core of more than 100 trillion rupiah that launched a mobile-based banking product called 'G-Apps' in 2016. G-Apps is a digital banking application, which enables customers to manage their finances using their mobile phones. G-Apps succeeded in garnering more than 350,000 new customers). G-Apps also connected with the national banking ecosystem under the national banking ecosystem under the supervision of national banking and financial regulator.

G-Apps have greatly increased the number of new accounts (opening account) with a target exceeding one million accounts by the end of 2018. However, B Bank has some troubles in enhancing marketers' productivity since the competition among banks in Indonesia are getting tight. It is seen on the different productivity levels in some points of sales (PoS). Even though the PoS have same infrastructure number in both system and total and composition of the marketers. The competition makes productivity need level to be stronger, yet it depends on the survival of business organizations in the middle of the competition (Smith, 1994).

A motivated employee is very necessary to keep the business in a growth phase. With more efficient and effective ways, the employee's motivation aspect could be monitored and maintained. It is also necessary to know the factors expected by employees to help decision maker in giving the right response. According to Duicâ (2008), motivation is defined as the whole driving force, either internal or external, which makes an individual have the willingness to do a job that is oriented on a certain goal. Deci and Gagne (2005) asserted that there is a correlation between motivation and work performance.

Therefore, this study aimed to know the positive and significant correlations of motivation variables, rewards and promotions, people development, with employee performance productivity in the banking business sector, particularly for marketers of mobile banking products who had applied the lean strategy pattern of management industry 4.0. Moreover, the research sought to determine the right strategy to optimize the marketers' productivity performance level.

\section{METHODOLOGY}

\section{Research Strategies}

This research strategy used descriptive research as an approach. The researcher gave explanations on the findings of correlation between variables, and did not make any judgment or interpretation on the conditions during the test (Creswell, 1994). The test itself was done using hypothesis verification on intended conditions. This research strategy used information accumulation of the basic problem experienced by offline units within the G- Apps product structure. The activity of account acquisition on and current account saving accounts (CASA) within the product structure was becoming the main target which influenced the key performance indicators of the unit. The general structure of the product development unit of G-Apps can be seen in Figure 1 below:

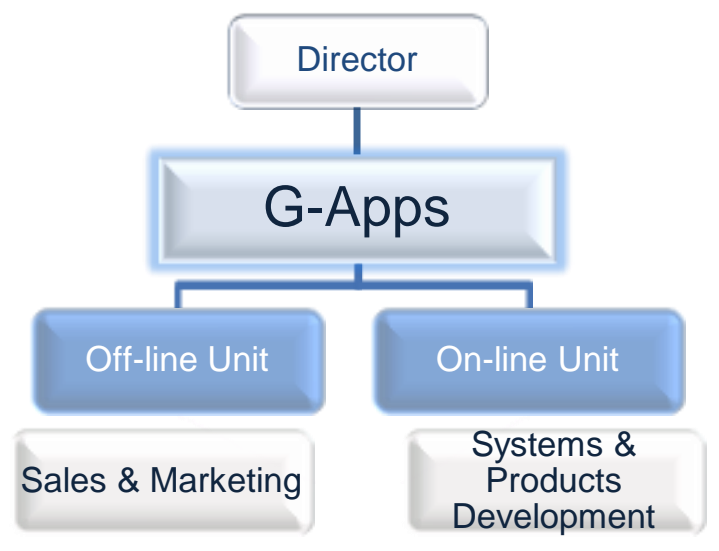

Figure 1. G-Apps' Functional Structure-B Bank 
Hence, the offline unit was fully responsible for the sales targets, including marketing activity. The operational strategy within the selling and new bank customer acquisition aspects divided the total of 250 marketers among three big cities: Jakarta and its surroundings, Bandung and Surabaya, with an 80:10:10 ratio spread over five sales points, namely: office to office, mall 1, mall 2, guerrilla, and communities. Each sales point was given one crew team consisting of a leader and two or three members. The description on the operational strategy can be seen in Figure 2 below:

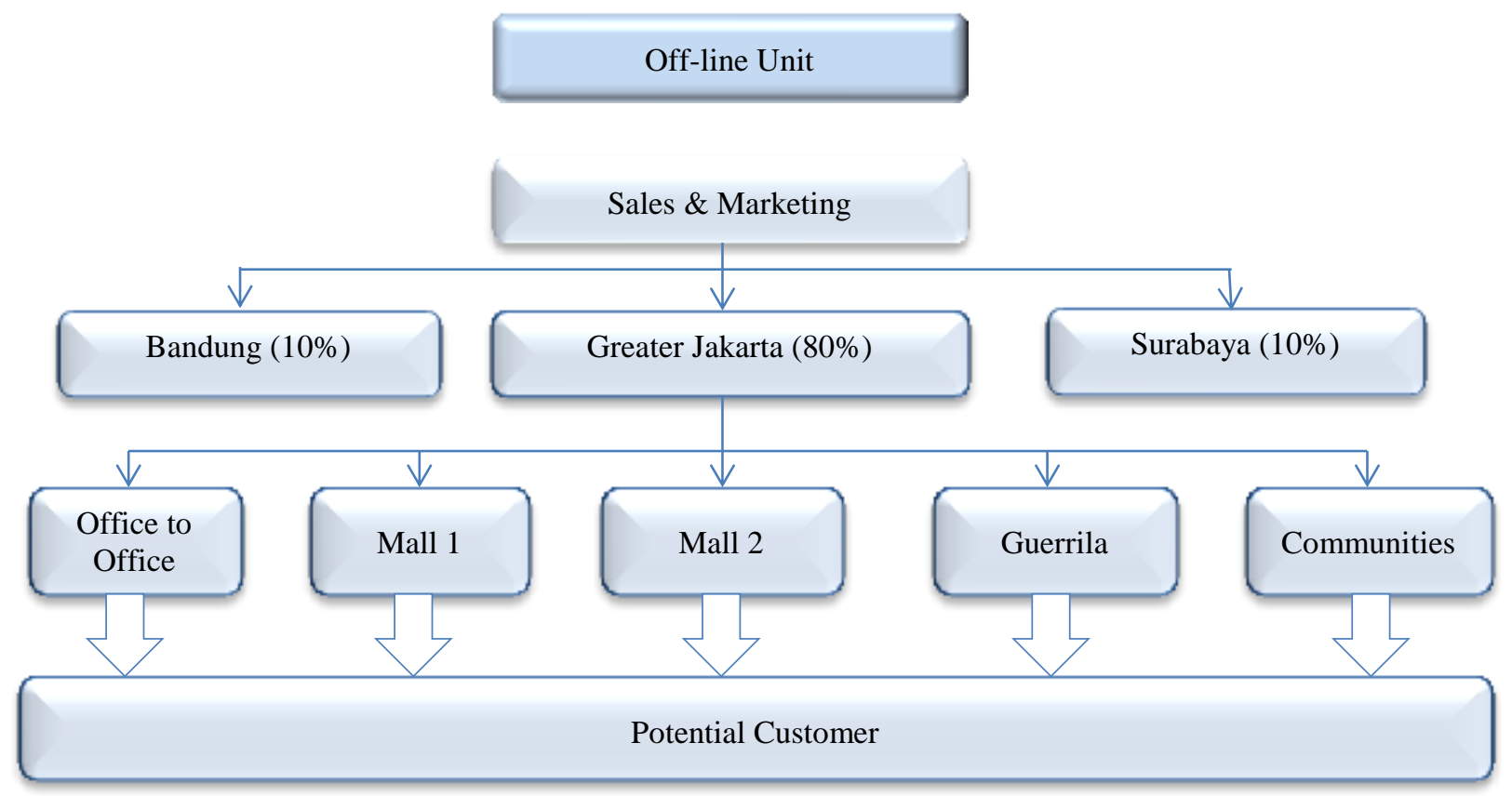

Figure 2. Operational Strategy in Placing the Marketers

\section{Sample Data}

The data collection planning was conducted considering the secret boundaries of bank data which had been managed in the agreement (NDA). This also affects the depth of data observation levels. The summary on data boundaries and type can be seen below:

a. Scope: the account acquisition process, which started from the registration process until card issuance through the perspective of operation process due to marketers' productivity enhancement.

b. Sample: three sub-channels PoS of mall 1 and mall 2: PoS 1 central Jakarta, PoS 2 south Jakarta, PoS 3 Bekasi. Also 3 sub-channels PoSv of mall 1 and mall 2; PoSv 1 south Jakarta, PoSv 2 south Jakarta, and PoSv 3 central Jakarta. Thus, the researcher could samples from 3 sub-channels that represent the average performance (on par), above average, and below average. The period on primary data observation was July till September 2018. The field survey was done on October week 4 until November week 1, 2018

c. The total respondent: the total of marketer population in each point was 33 people (the total resource per point was 5-6 people).

\section{Instruments and Measures}

There were two main objectives in measuring the survey. The first objective was finding the connection between different variables which triggered from the predictor variables of motivation, trust and satisfaction. The second was digging up information on different respondent data characteristics to know the variation patterns that probably create different results from previous modeling series. 
Dhayawardhana Adhie, Jemy Wicaksono and Ahmad Syamil (2019). "The implication of lean process Industry 4.0 on service company: motivation on marketer productivity enhancement", Management and entrepreneurship: trends of development, 3(09), pp. 8-20. DOI: https://doi.org/10.26661/2522-1566/2019-3/09-01

In order to discuss those two main objectives, a questionnaire model was arranged and grouped based on the variable category. The questionnaire was arranged under the adaption model which replicated from the literature. The first variable was employee motivation with six items obtained from Chang and Cehn (2008); the next variable was the employee performance with three items from Chen's (2010) research result. Then, recognition or promotion variable with five items was gathered through Patterson and Spreng (1997). The last variable which was tested was people development with four items taken from Armstrong and Kotler's (2009) work. Table 1 below shows questionnaire summary which was based on variable categories:

Table 1

Questionnaire summary table with four variables

\begin{tabular}{|c|c|c|c|}
\hline Number & Variable & Items & Reference \\
\hline 1 & Employee motivation & $\begin{array}{l}\text { 1. I feel a sense of personal satisfaction when I do } \\
\text { this job well } \\
\text { 2. My opinion of myself goes down when I do } \\
\text { the job badly } \\
\text { 3. I take pride in doing my job as well as I can } \\
\text { 4. I feel unhappy when my work is not up to } \\
\text { usual my standard } \\
\text { 5. I like to look back at a day's work with a sense } \\
\text { of a job well done } \\
\text { 6. I try to think if ways of doing my job } \\
\text { effectively }\end{array}$ & $\begin{array}{l}\text { (The McKinsey } \\
\text { Quarterly, 2006) }\end{array}$ \\
\hline 2 & Employee performance & $\begin{array}{l}\text { 1. My performance is better than that of my } \\
\text { colleagues with similar qualifications } \\
\text { 2. I am satisfied with my performance because } \\
\text { it's mostly good } \\
\text { 3. My performance is better than that of bankers } \\
\text { with similar qualifications in other banks }\end{array}$ & Bishop, 1987 \\
\hline 3 & Intrinsic reward & $\begin{array}{l}\text { 1. The organization allow them to grow as a } \\
\text { person, improve self confidence overcome the } \\
\text { weakness, mature foster their self esteem } \\
\text { 2. Their activity in the organization matches/it's } \\
\text { their ethics and moral values. } \\
\text { 3. The organization environment, in which their } \\
\text { activity is embedded is cooperative, and foster } \\
\text { mutual respect, and there is friendship and } \\
\text { interpersonal trust among employees } \\
\text { 4. The organization is fair regarding internal } \\
\text { management procedures/method } \\
\text { They have sense of belonging regarding } \\
\text { organization themselves a part of organization } \\
\text { are loyal/faithful to the organization }\end{array}$ & Frey (1997) \\
\hline 4 & $\begin{array}{l}\text { Employee } \\
\text { effectiveness }\end{array}$ & $\begin{array}{l}\text { 1. My company provides me the opportunity to } \\
\text { improve my skills } \\
\text { 2. There is lot of chance to learn new things in } \\
\text { this company } \\
\text { 3. My company frequently arranges training } \\
\text { programs of the employees } \\
\text { 4. Doing job in this company will benefit to me }\end{array}$ & $\begin{array}{l}\text { (Chiaburu and } \\
\text { Tekleab, 2005) }\end{array}$ \\
\hline
\end{tabular}

\section{Extent of researcher interface}

In this study, the researcher was involved as a moderate interference. A moderate interference has the job of ensuring the ratio correlation on causal relationships between (as-is) process which 
was done by the marketer's productivity results. It had a strong correlation by abandoning the other aspects which were considered as having weak relationships.

\section{Extent of Researcher Interference}

In this study, the researcher became the moderate interference who was ensuring the ratio correlation on causal relationship between the (as-is) process. It was done by the marketers' productivity result as strong correlation by ignoring the other aspects.

\section{Study Setting}

The samples were taken from some points of sales in Jakarta and its surroundings with field studies as a research design.

\section{Unit of Analysis (Population to be Studied)}

Based on the configuration of the marketers placement in every sales point as shown in Figure 3 , then the unit of analysis was in the form of groups without considering the equality of the marketers' numbers.

\section{Time Horizon}

This study used longitudinal studies as the research time horizon since it was limited on the observation period to July, August and September 2018.

\section{Proposal Sampling Method and Process}

Through the total number of 250 marketer crews, around $50-60$ sales group were spread to five sub channels (office to office, mall 1, mall 2, guerrilla and communities) in three big cities. The sampling process was done by taking three groups in every sales point with target performance category as: 1 on par average, 1 above average, and 1 below average in Jakarta and Bekasi. The sampling proposal was conducted in the mall 1 and mall 2 group in five different locations: booths at PoS 1 (central Jakarta), PoS 2 (south Jakarta), PoS3 (Bekasi), PoSv 2, and PoSv 3. Since every element was assumed in having population representation element, then the sampling design used in this study was probability sampling. To test the difference performance of each group, disproportionate stratified random sampling was used.

\section{Proposed Data Collection Technique}

Since this study used descriptive research, a questionnaire was used as the data collection technique. As respondents the marketers and customer in some PoS in every city were involved. It had the purpose of supporting the observation on goodness of data with quantitative aspects, such as demography of the respondents (long work period, work position, work group) and employee moral engagement (motivation, work life), customer satisfaction and others. The question format was arranged based on a Likert scale with 5 lines (ranging from strongly disagree to strongly agree). The question pattern was arranged using multiple questions with some open-ended question in the last part.

\section{Proposed Statistic Analysis}

From the data collection process, the analysis focused on the aspect of goodness of the data with descriptive statistic approach, such as: central tendency, correlation and projection analysis between the two predictor variables. ANOVA and multiple regression was used to test the hypothesis and make the final projection result based on time series. The measurement used scaling with interval scale and ratio scale types. The interval scale was used for measuring the reliability variable, while the ratio scale was for measuring the productivity.

\section{RESULTS AND DISCUSSION}

The onboarding process of G-Apps of B Bank customer was started from a registration process and data validation on mobile phone guided by the marketer in every point of sale. Then the CMS system generated the card activation process as the final activation process if the registration was approved. In the final process, the marketer gave directions on the advantages and benefits to 
Dhayawardhana Adhie, Jemy Wicaksono and Ahmad Syamil (2019). "The implication of lean process Industry 4.0 on service company: motivation on marketer productivity enhancement", Management and entrepreneurship: trends of development, 3(09), pp. 8-20. DOI: https://doi.org/10.26661/2522-1566/2019-3/09-01

bank customers. For customers who wanted to recharge or top up on the same day they made sure the registration could use the account directly for saving money or other payment processes. Through the three points of sales ( $\operatorname{PoS} 2, \operatorname{PoS} 1$, and PoS 3), in the three months of observation (July, August, September, 2018), the data were finally obtained as seen in Figures 3 and 4 below:

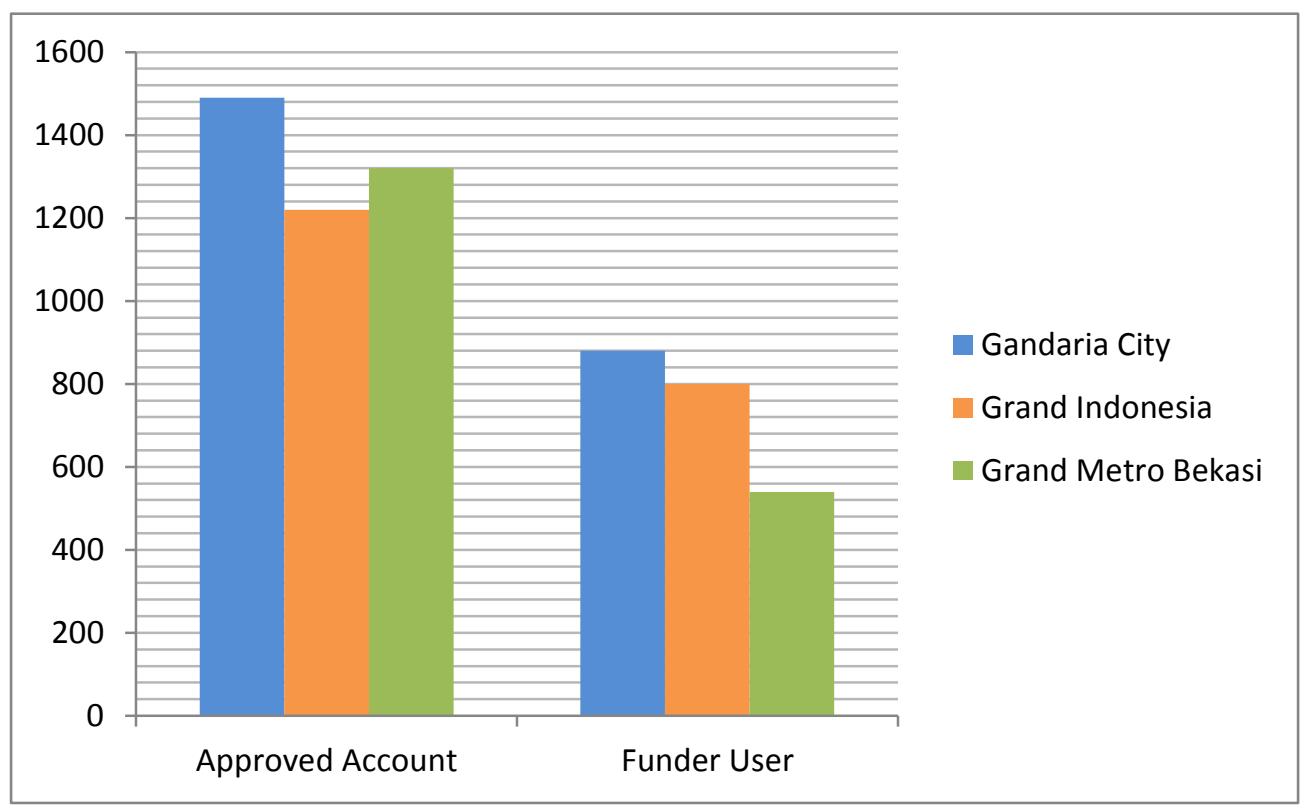

Figure 3. Graphic of Approved Accounts and Funded Users

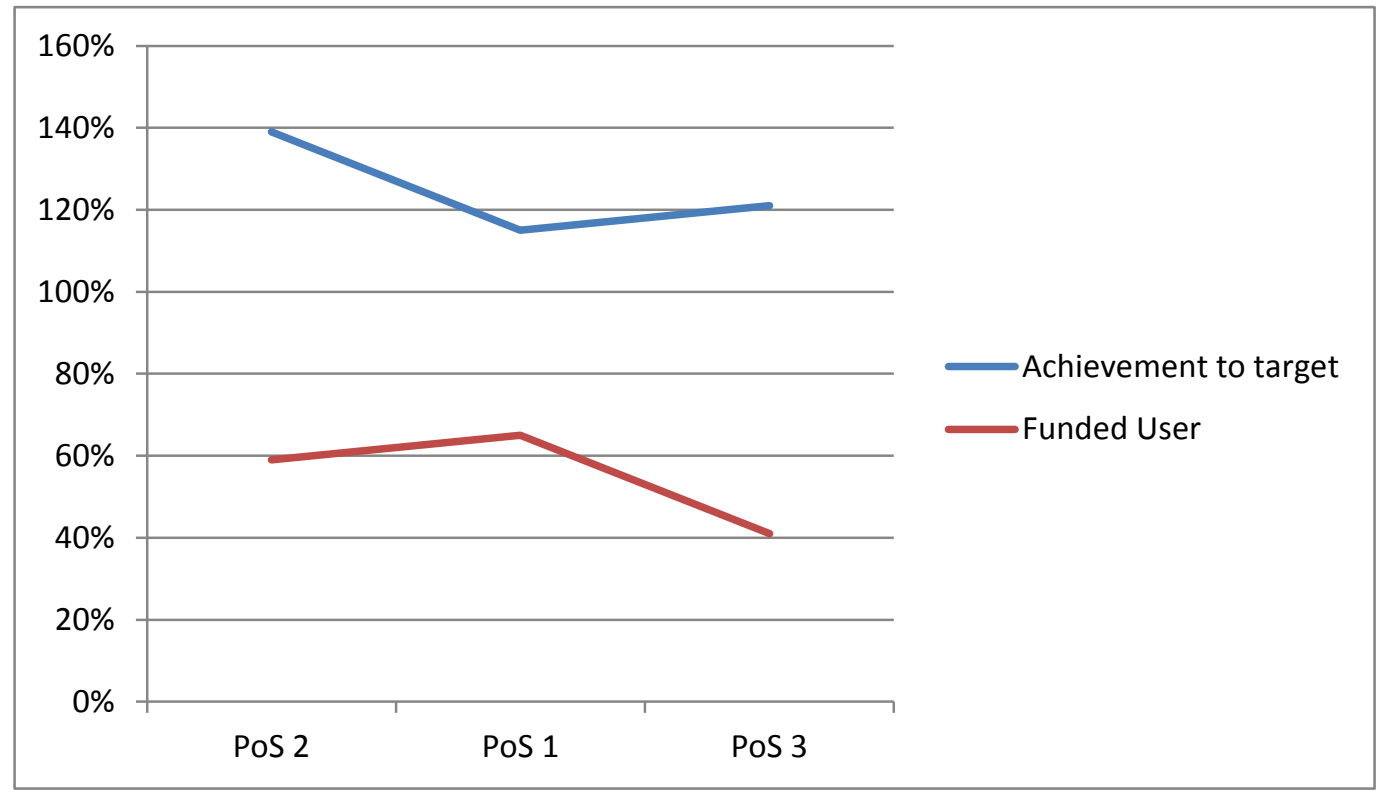

Figure 4. Graphic of Target Achievements and Funded Users

From the figures above, it could be seen that the tendency of approved accounts from the three points of sales had an average score above target $(1.088$ account $/ \mathrm{month} / \mathrm{PoS})$ for $120 \%$ per PoS. PoS 1 had a low percentage of the achievement than the other two PoS. However, from the funded user category, the ratio of PoS 1 was on top of the achievements for about $70 \%$ 
and $59 \%$ for recharging on the same day. Based on the marketers' SOP (Standard Operating Procedures), the productivity of marketers could be assumed as good.

\section{ANALYSIS}

\section{Respondent profile}

This study was conducted on 33 respondents. The respondents were observed based on demography level, such as respondent's job position (leader and crew), job function (sales, service, or other), point of sales or service (PoS 1 central Jakarta; PoS 2 south Jakarta, PoS 3 Bekasi, PoSv 1 , and PoSv 3), the respondent's working period (less than 6 months until 12 months, and more than 12 months), working experience, and respondent's role in taking decision. All of the respondents gave responses on the survey without missing data.

The respondent profile on job position showed 93.3\% worked as crew and $6.1 \%$ as leader. The job function was dominated by sales (63.6\%), service (33.3\%), and others (3\%). The total respondents based on region were $33.3 \%$ in PoS 2, 27.3\% in PoS 3, 18.2\% in PoSv 1, 15.2\% in PoS 1 and $6.1 \%$ in PoS 3. The respondent's working period for more than 12 months was 36.4\%, between 6 until 12 months was 36.4\% and less than 6 months was 27.3\%. Most of the respondents $(60.6 \%)$ were experienced in their field, while the rest of $(39.4 \%)$ were new in their field. Meanwhile, the respondent's profile based on the decision-maker role showed that there were $48.5 \%$ of respondents who were active, $30.3 \%$ were active if asked or needed, $18.2 \%$ were less involved, and the rest (3\%) were not involve in making decisions.

\section{Validity and Reliability Analysis}

The validation and reliability test were done on a trust level of $95 \%$ and error level of $5 \%$ for all measured instruments from all variables. The motivation variable was measured with six survey questions; there were three questions for performance variable, five questions for promotion recognition variable, and four questions for personal development variable.

The validation test result on the motivation variable (MOT) had a KMO score of $>0.6$ with a significance score of $0.000<0.05$. The communalities and matrix component showed $>0.5$ which meant the instrument used valid measurements in presenting the construct variable. Meanwhile, the reliability test showed a Cronbach's Alpha score of $0.714>0.7$ and a matrix correlation for all instruments had a score of $>0.5$ which meant that the instrument was reliable for construct variable measurement.

The validation test result on performance variable (PER) had a KMO score measuring $0.618>$ 0.6 with a significance score of $0.000<0.05$. The communalities and matrix component showed $>$ 0.5 which meant the instrument was valid measurement in presenting the construct variable. Meanwhile, the reliability test showed the Cronbach's Alpha score of $0.768>0.7$ and the matrix correlation for all instruments showed a score of $>0.5$ which meant the instrument was reliable in construct variable measurement.

The validation test result on recognition promotion variable (PR) had a KMO score of $0.724>$ 0.6 with a significance score of $0.000<0.05$. The communalities and matrix component showed $>$ 0.5 which meant the instrument used was a valid measurement in presenting the construct variable. Meanwhile, the reliability test showed the Cronbach's Alpha score of $0.76>0.7$ and matrix correlation for all instruments for $>0.5$ which meant the instrument was reliable in construct variable measurement.

The validation test result on personal development variable (PDV) had a KMO score of 0.649 $>0.6$ with significance score of $0.000<0.05$. The communalities and matrix component showed > 0.5 which meant the instrument used was a valid measurement presenting the construct variable. Meanwhile, the reliability test showed the Cronbach's Alpha score for $0.850>0.7$ and matrix correlation for all instruments for $>0.5$ which meant the instrument was reliable in construct variable measurement. 
Dhayawardhana Adhie, Jemy Wicaksono and Ahmad Syamil (2019). "The implication of lean process Industry 4.0 on service company: motivation on marketer productivity enhancement", Management and entrepreneurship: trends of development, 3(09), pp. 8-20. DOI: https://doi.org/10.26661/2522-1566/2019-3/09-01

Therefore, the whole measurement instruments were valid and reliable enough in conducting measurement of the variables.

\section{Hypothesis Testing}

The hypothesis testing was done using regression multivariate analysis on a trust level of $95 \%$ and error of 5\%. Based on Figure 1 above, the construct correlation test was done in multivariate way between variable rework promotion (RP), people development (PDV), and motivation (MOT) in productivity performance (PER).

\section{Model Summary ${ }^{\mathrm{b}}$}

\begin{tabular}{|c|c|c|c|c|}
\hline Mode & $\mathrm{R}$ & R Square & $\begin{array}{c}\text { Adjusted R } \\
\text { Square }\end{array}$ & $\begin{array}{c}\text { Std. Error of the } \\
\text { Estimate }\end{array}$ \\
\hline 1 & $.386^{\mathrm{a}}$ & .149 & .061 & .65931 \\
\hline
\end{tabular}

a. Predictors: (Constant), MOT, RP, PDV

b. Dependent Variable: PER

\begin{tabular}{|c|c|c|c|}
\hline R & R Square & $\begin{array}{c}\text { Adjusted R } \\
\text { Square }\end{array}$ & $\begin{array}{c}\text { Std. Error of the } \\
\text { Estimate }\end{array}$ \\
\hline 0.386 & 0.149 & 0.061 & 0.65931 \\
\hline
\end{tabular}

a. Predictors: (Constant), MOT, RP, PDV

b. Dependent Variable: PER

\section{Figure 5. R Square Model}

From Figure 5 above it could be seen that the correlation score on predictor variables (RP, PDV, MOT) only described the contribution of $14.9 \%$ towards dependent variable PER. It meant that there was $85.1 \%$ of other variable factors which cannot be defined yet. In recap, all of the data from the regression test of data multivariate variables can be seen in Figure 9 below:

\begin{tabular}{|c|c|c|c|c|c|c|}
\hline Hypothesis & $\begin{array}{c}\text { Independent } \\
\text { Variable }\end{array}$ & $\begin{array}{c}\text { Dependent } \\
\text { Variable }\end{array}$ & Estimate & T-Value & Sig. & Result \\
\hline H1 & MOT & PER & 0.641 & 2.004 & 0.050 & Supported \\
\hline H2 & RP & PER & 0.340 & 0.928 & 0.361 & Not Supported \\
\hline H3 & RP & MOT & 0.039 & 0.189 & 0.852 & Not Supported \\
\hline H4 & PDV & MOT & 0.325 & 2.205 & 0.035 & Supported \\
\hline H5 & PDV & PER & -0.408 & -1.466 & 0.153 & Not Supported \\
\hline
\end{tabular}

\section{Figure 6. Hypotheses Model}

H1: Motivation gave a positive impact on marketers' productivity level for $64.1 \%$. This first hypothesis test showed the relation between motivations as a mediating variable on productivity performance was significant enough. It had a significance score of $0.05(<0.05)$ and a $t$-value score for $2.004(>1.96)$.

H2: Recognition or promotion made a positive impact on marketers' performance productivity level for $34 \%$. However, the result of the regression analysis on this hypothesis showed the relationship between recognition promotion and productivity was insignificant. A significance score measured $0.361>0.05$ and a t- value score of $0.928(<1.96)$. 
H3: Recognition or promotion made a small positive impact on marketers' motivation for $3.9 \%$. The hypothesis result showed the relationship between recognition promotion and motivation was also insignificant, in which the significance score measured was $0.852>0.05$ and the $\mathrm{t}$-value score was $0.189(<1.96)$.

H4: People development programs made a positive impact on marketers' motivation level for $32.5 \%$. The hypothesis result showed that the relation between people development and motivation was significant enough with positive direction with a significance score of $0.035<0.05$ and a tvalue of 2.205 (> 1.96).

H5: People development program made a negative impact on marketers' productivity level which decreased $40.8 \%$. The hypothesis result showed that the relation between people development and productivity level was insignificant, with a significance score of $0.153>0.05$ and t-value for $-1.466(<1.96)$.

Therefore, it could be seen that from some constructed variables of productivity performance, the mediating motivation variable (MOT) made a positive impact and was quite significant. Meanwhile, from the two predictor variables, reward promotion (RP) and people development (PDV) did not give any positive impact and significance on productivity performance dependent variable (PER). However, specifically, people development could make a positive and significant impact on mediating motivation variable (MOT).

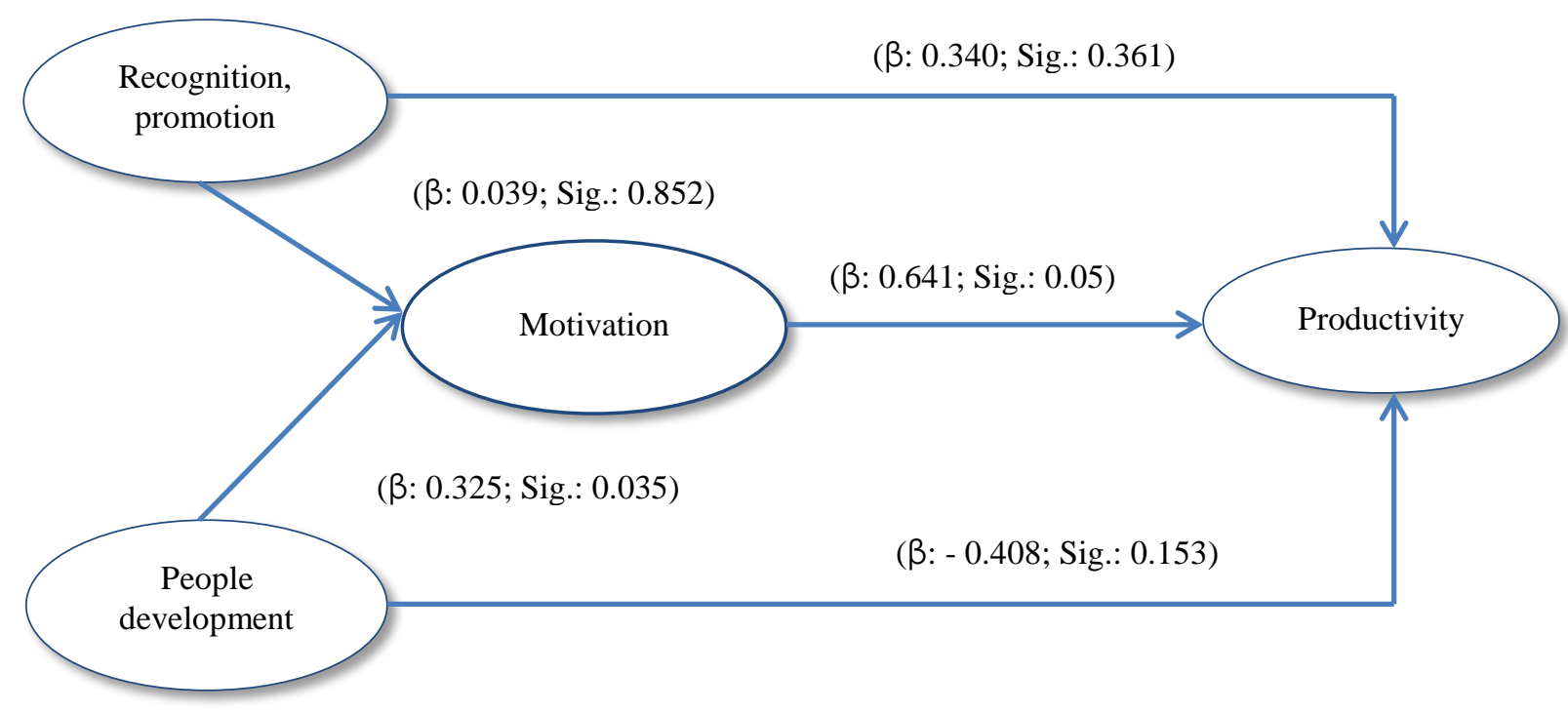

Figure 7. The Results of the Multivariate Correlation Test

The hypothesis test result showed that not all of the predictor variable components (recognition promotion and people development) were able to make a positive impact on the productivity performance rather than the mediating variable (motivation). However, people development also had a positive impact on marketers' motivation which then influenced the productivity performance.

From the respondent demography aspect, generally, the respondents performed well and were satisfied with the working result which showed an average score of 3.9 (scale 5). A few of respondent $(9 \%)$ felt doubt and were not yet satisfied with the worker results. These $9 \%$ of the respondents were coming from the service crew position who worked for more than 12 months in Pondok Indah Mall and Lotte Avenue PoS. Respondents of sales leader position who worked for less than 12 months agreed and strongly agreed with the job satisfaction and productivity. 
Dhayawardhana Adhie, Jemy Wicaksono and Ahmad Syamil (2019). "The implication of lean process Industry 4.0 on service company: motivation on marketer productivity enhancement", Management and entrepreneurship: trends of development, 3(09), pp. 8-20. DOI: https://doi.org/10.26661/2522-1566/2019-3/09-01

\section{CONCLUSIONS}

Based on the results, the person in charge of the product was hoped to make a concept of productivity measurement construction that focused on the effort of non-intrinsic refinement. It was an implementation of the employee's development program either in the short term such as regular sales clinics, training programs based on function level and periodic rotation from each PoS or a service, especially for a certain region with different market segmentation challenges (Jakarta vs Bekasi). Moreover, for service areas, it was recommended to immediately develop the comprehensive measurement and monitoring concept toward the productivity level. Since the marketer was dominated by the millennial generation with working periods of less than a year, then it needed a certain approach to keep the continuity through an interesting retention program.

\section{SUGESSTION}

This study has identified the relation between motivation factors as a mediation variable with productivity performance variables in some PoS from the mobile banking product G-Apps . Even though the scope of this study was small and limited on five points of sales and services in Jakarta and Bekasi, in general the researcher could have conducted a multistage study by taking a bigger sample from various cities and the operational strategy of the marketers' placement. Thus, for further research the researcher suggests to increase the sample numbers in order to increase the variation of the results for every possibility.

The results of this study found that there was a necessity to define another motivation factor that was probably noticed by the marketers and could affect their productivity performance levels. Considering other motivations which were not mentioned in this study, then it is expected for further research to add some factors such as the employee's satisfaction factor, self-leadership, interest or enthusiasm, or some other intrinsic and non-intrinsic factors. These were expected to influence the moderation effect and increase the $\mathrm{R}$ square ratio or the adjusted score toward the predictor variables of productivity performance.

\section{REFERENCES}

Ahmad, M.B., Wasay, E. and Jhandir, S. U. (2012). "Impact of Employee Motivation on Customer Satisfaction: Study of Airline Industry in Pakistan", Interdisciplinary Journal of Contemporary Research in Business, 4(6), 531-539. Available at SSRN: https://ssrn.com/abstract=2183591

Alwan, L. C. (2000). Statistical Process Analysis, McGraw-Hill.

Asim, M. (2013). "Impact of Motivation on Employee Performance with effect of training: Specific to Education Sector of Pakistan", International Journal of Scientific and Research Publications, 3(9), pp. 1-9. Available at: http://www.ijsrp.org/research-paper-0913/ijsrpp21120.pdf

Barber, A.E., Dunham, R.B. and Formisano, R.A. (1992). "The impact of flexible benefits on employee satisfaction: a field study", Personnel Psychology, 45(1), pp.55-74. Available at: http://dx.doi.org/10.1111/j.1744-6570.1992.tb00844.x.

Bassett-Jones, N. and Lloyd, G. C. (2005). "Does Herzberg's motivation theory have staying power?", Journal of management development, 24(10), pp. 929-943. Available at: https://doi.org/10.1108/02621710510627064

Chen, Y. and Lou, H. (2002). "Toward an Understanding of the Behavioral Intention to Use a Groupware Application", Journal of Organizational and End User Computing, 14(4), pp.116. Available at: http://dx.doi.org/10.4018/joeuc.2002100101. 
Posselt, T., 2003. Frey, Bruno/Osterloh, Margit and Swiss Association for Organization and Management (ed.), Successful Management by Motivation - Balancing Intrinsic and Extrinsic Incentives, Springer-Verlag, Berlin u.a. 2002, Schmalenbach Business Review, 55(4), pp.342343. Available at: http://dx.doi.org/10.1007/bf03396682.

Ganta, V. C. (2014). "Motivation in the workplace to improve the employee performance", International Journal of Engineering Technology, Management and Applied Sciences, 2(6).

Ghaffari, S., Shah, I., Burgoyne, J., Nazri, M. and Salleh, J. (2017). The Influence of Motivation on Job Performance: A Case Study at Universiti Teknologi Malaysia, Aust. J. Basic \& Appl. Sci, 11(4), pp. 92-99.

Hair, J. F., Black, W. C., Babin B. J. and Anderson, R. E. (2014). Multivariate Data Analysis, 7th edition, Pearson.

Joseph, O. B. (2015). "The Effect Of Employees' Motivation On Organizational Performance", Journal of Public Administration and Policy Research, 7(4), pp. 62-75. Available at: https://doi.org/10.5897/jpapr2014.0300

Kaydos, W. (1999). Operational Performance Measurement - Increasing Total Productivity, St.Lucie Press, CRC Press LLC.

Lehnert, M., Linhart, A. and Röglinger, M. (2016). „Value-based process project portfolio management: integrated planning of BPM capability development and process improvement", Business Research, 9(2), pp. 377-419.Available at:https://doi.org/10.1007/s40685-016-0036-5

Olusadum, N. J. and Anulika, N. J. (2018). "Impact of Motivation on Employee Performance: A Study of Alvan Ikoku Federal College of Eduaction", Journal of Management and Strategy, 9(1), pp. 53-65. Available at: https://doi.org/10.5430/jms.v9n1p53

Junior, P., Alves, M. J. and Mendes, J. V. (2017). "Operational practices of lean manufacturing: Potentiating environmental improvements", Journal of Industrial Engineering and Management (JIEM), 10(4), pp. 550-580. Available at: https://doi.org/10.3926/jiem.2268

Robescu, O. and Iancu, A. G. (2016). "The Effects of Motivation on Employees Performance in Organizations", Valahian Journal of Economic Studies, 7(2), pp.49-56. Available at: https://doi.org/10.1515/vjes-2016-0006

Rowden, R. W. and Conine Jr, C. T. (2005). "The impact of workplace learning on job satisfaction in small US commercial banks", Journal of workplace Learning, 17(4), pp. 215-230. Available at: https://doi.org/10.1108/13665620510597176

Sanders, A., Elangeswaran, C. and Wulfsberg, J. P. (2016). "Industry 4.0 implies lean manufacturing: Research activities in industry 4.0 function as enablers for lean manufacturing", Journal of Industrial Engineering and Management (JIEM), 9(3), pp. 811833. Available at: http://dx.doi.org/10.3926/jiem.1940

Schroeder, R. G. (2008).Operations Management, Contemporary Concept and Cases, McGrawHill.

Sekaran, U. and Bougie, R. (2017). Research Methods for Business, 7th edition, Wiley.

Shahzadi, I., Javed, A., Pirzada, S. S., Nasreen, S. and Khanam, F. (2014). "Impact of employee motivation on employee performance. European Journal of Business and Management", 6 (23), pp. 159-166.

Tsai, P. C. F., Yen, Y. F., Huang, L. C. and Huang, C. (2007). “A study on motivating employees' learning commitment in the post-downsizing era: Job satisfaction perspective", Journal of World Business, 42(2), pp. 157-169. Available at: https://doi.org/10.1016/j.jwb.2007.02.002

Wang, L., Herve, D. B. G. and Shen, Y. (2012). "Continuous process improvement in banking sector and a model design for performance enhancement", International Journal of Business and Management, 7(2). Available at: https://doi.org/10.5539/ijbm.v7n2p130 
Dhayawardhana Adhie, Jemy Wicaksono and Ahmad Syamil (2019). "The implication of lean process Industry 4.0 on service company: motivation on marketer productivity enhancement", Management and entrepreneurship: trends of development, 3(09), pp. 8-20. DOI: https://doi.org/10.26661/2522-1566/2019-3/09-01

\section{ВПРОВАДЖЕННЯ ОЩАДЛИВОГО ВИРОБНИЦТВА ТА КОНЦЕПЦЇ̈ INDUSTRY 4.0 НА СЕРВІСНОМУ ПІДПРИЕМСТВІ ЯК МОТИВАЦІЯ ПІДВИЩЕННЯ ПРОДУКТИВНОСТІ МАРКЕТЕРА}

\author{
Dhayawardhana Adhie \\ Університет Бінус \\ (Біна Нусантара) \\ Дожакарта, Індонезія
}

\author{
Jemy Wicaksono \\ Університет Бінус \\ (Біна Нусантара) \\ Джакарта, Індонезія
}

\author{
Ahmad Syamil \\ Університет Бінус \\ (Біна Нусантара) \\ Дюжакарта, Індонезія
}

Промисловість 4.0 відома як безперервна промислова революція, яка відрізняється швидким розвитком завдяки оптимізаційним процесам, підтримуваним технологічними інноваціями 3 кінця 1970-х. Це зробило обробну промисловість більш продуктивною 3 ефективними експлуатаційними витратами завдяки безперервним інформаційним додаткам технологій, що підтримуються комунікаційними системами футуристичної технології. Однак на ранніх етапах впровадження часто зустрічалися перешкоди, такі як занадто низькі показники рахунків та дуже посередня кількість нових клієнтів за час, відзначений високою продуктивністю маркетологів у цій галузі. Одним із факторів, що вплинули на рівень продуктивності працівника, була мотивація. Мотивація розглядається як сила, яка змушує працівників досягати конкретних цілей і завдань в організаціях. Проведене дослідження мало на меті визначити чинники, що впливають на мотивацію роботи в галузі фінансових послуг на основі мобільних банківських додатків. Воно також було спрямовано на визначення рівня впливу мотивації на робочу ефективність працівників. Для визначення рівня ефекту мотивації працівника на робочу ефективність як метод застосовувався підхід регресійного аналізу шляхом додавання інших змінних. Таким чином, змінна була проаналізована на предмет наявності позитивної та значної кореляції зі змінною продуктивністю. Результат показав, що існувала значна позитивна кореляція між мотивацією та продуктивністю маркетерів. Дві інші змінні дали різну відповідь. Також в результаті дослідження було виявлено необхідність визначення іншого фактора мотивації, який, як вбачається, має значний вплив на рівень продуктивності маркетерів. Таким чином, можна зробити висновок, що розрізнення галузей за продуктом, робочою схемою та фоном працівників впливає на результат придатності між мотивацією працівника та рівнем продуктивності.

Ключові слова: індустрія 4.0, мотивація, винагорода, просування, розвиток персоналу, підвищення продуктивності.

\section{ВНЕДРЕНИЕ БЕРЕЖЛИВОГО ПРОИЗВОДСТВА И КОНЦЕПЦИИ INDUSTRY 4.0 НА СЕРВИСНОМ ПРЕДПРИЯТИИ КАК МОТИВАЦИЯ ПОВЫШЕНИЯ ПРОИЗВОДИТЕЛЬНОСТИ МАРКЕТЕРА}

\author{
Dhayawardhana Adhie \\ Университет Бинус \\ (Бина Нусантара) \\ Джкакарта, Индонезия
}

\author{
Jemy Wicaksono \\ Университет Бинус \\ (Бина Нусантара) \\ Джсакарта, Индонезия
}

\author{
Ahmad Syamil \\ Университет Бинус \\ (Бина Нусантара) \\ Джакарта, Индонезия
}

Промышленность 4.0 известна как непрерывная промышленная революция, которая отличается быстрым развитием благодаря оптимизационным процессам, поддерживаемым технологическими инновациями с конца 1970-х. Это сделало обрабатывающую промышленность более продуктивной с эффективными эксплуатационными затратами благодаря непрерывным информационным приложениям технологий, поддерживаемых коммуникационными системами футуристической технологии. Однако на ранних этапах внедрения часто встречались препятствия, такие как слишком низкие показатели счетов и очень посредственное количество новых клиентов за время, отмеченное высокой 
производительностью маркетологов в этой области. Одним из факторов, повлиявших на уровень производительности работника, была мотивация. Мотивация рассматривается как сила, которая заставляет работников достигать конкретных целей и задач в организациях. Проведенное исследование имело целью определить факторы, влияющие на мотивацию работы в области финансовых услуг на основе мобильных банковских приложений. Оно также было направлено на определение уровня влияния мотивации на рабочую эффективность сотрудников. Для определения уровня эффекта мотивации работника на рабочую эффективность как метод применялся подход регрессионного анализа путем добавления других переменных. Таким образом, переменная была проанализирована на предмет наличия положительной и значительной корреляции с переменной производительностью. Результат показал, что существовала значительная положительная корреляция между мотивацией и производительностью маркетеров. Две другие переменные дали разные ответы. Также в результате исследования была выявлена необходимость определения иного фактора мотивации, который, видимо, имеет значительное влияние на уровень производительности маркетеров. Таким образом, можно сделать вывод, что разделение отраслей по продукту, рабочей схеме и фоном работников влияет на результат пригодности между мотивацией работника и уровнем производительности.

Ключевые слова: индустрия 4.0, мотивация, вознаграждение, продвижение, развитие персонала, повышение производительности. 